\title{
"A eloqüência farfalhante da tribuna do júri": o tribunal popular e a lei em Nelson Hungria
}

Ricardo SONTAG ${ }^{\bullet}$

\begin{abstract}
Resumo: Este artigo pretende analisar a questão do júri no pensamento do penalista Nelson Hungria levando em consideração o contexto histórico das transformações sofridas pelas instituições penais durante o Estado Novo (particularmente as leis sobre o júri e os códigos penal e de processo penal de 1940 e 1941 respectivamente), até o post scriptum do percurso com as modificações trazidas pela Constituição de 1946 e pela lei 268 de 1947 e os seus escritos mais tardios. O aspecto chave a ser considerado nesse percurso é a (in)distinção no uso por parte de Hungria dos argumentos do tecnicismo jurídico-penal em relação àqueles do positivismo criminológico dependendo do contexto histórico.
\end{abstract}

Palavras-chave: História do Direito; Estado Novo; Júri; Nelson Hungria.

Em janeiro de 1938, isto é, pouco tempo depois do golpe de Getúlio Vargas que marcou o início do chamado 'Estado Novo' em novembro de 1937, o então ministro da Justiça Francisco Campos assina o decreto-lei 167 que regulava a instituição do júri. Abordar o júri no pensamento de Nelson Hungria quase se confunde com a trajetória do tribunal popular no Estado Novo, afinal, ele esteve presente na comissão de redação do referido

\footnotetext{
- Doutorando em História do Direito; pesquisador do Ius Commune Grupo de Pesquisa em História da Cultura Jurídica (CNPq/UFSC). Dipartimento di Teoria e Storia del Diritto - Università degli Studi di Firenze - UNIFI - Via delle Pandette, 35, CAP 50127, ed. D4 - FirenzeFI - Itália. E-mail: ricardosontag@yahoo.com.br
} 
decreto-lei, bem como na comissão que redigiu o código de processo penal de 1941.

O objetivo, aqui, porém, não é traçar a história do tribunal popular durante o Estado Novo ${ }^{1}$, nem destrinchar as minúcias técnicas da regulamentação do decreto-lei 167 e, depois, do código de processo penal. No pensamento de Nelson Hungria, o júri é central na questão do uso do texto do então novo código penal - também este feito durante o Estado Novo e com a presença de Hungria na comissão que o redigiu -, envolvendo, ainda, toda uma concepção de saber jurídico que se colocava como ponte entre o texto da lei e a aplicação da norma nos tribunais.

Compreender a questão do júri em Nelson Hungria levando em consideração, portanto, o contexto histórico das transformações sofridas pelas instituições penais durante $\mathrm{o}$ Estado Novo (particularmente as leis sobre o júri e os códigos penal e de processo penal de 1940 e 1941 respectivamente), até o post scriptum do percurso com as modificações trazidas pela Constituição de 1946 e pela lei 268 de 1947 e os escritos mais tardios de Hungria. No sentido de adensar a especificidade histórica do pensamento de Hungria em relação ao júri, ao invés de buscar as origens remotas dos seus argumentos (que, em si, não são, de fato, muito "originais"2) diluindo a sua voz em durações demasiado longas, será dado maior privilégio ao contexto da sua concepção de saber jurídico e de lei.

A consideração dos contextos nos quais se move o pensamento de Hungria é essencial, também, para a hipótese que pretendo levantar aqui em relação ao tipo de argumento utilizado por Nelson Hungria contra o júri. Embora as críticas de Hungria antes e depois da queda do Estado Novo, antes e depois da Constituição de 1946, sejam enquadráveis em um mesmo esquema teórico, considerar a diferença entre esses contextos torna possível adensar ainda mais a leitura histórica.

Com o avanço do positivismo criminológico ${ }^{3}$, dos estudos psiquiátricos, biossociológicos, a respeito do criminoso entre o final do séc. XIX e primeiras décadas do séc. XX, a série de argumentos relacionados à necessidade de uma adequada 
"A ELOQÜÊNCIA FARFALHANTE DA TRIBUNA DO JÚRI"....

especialização científica na administração da justiça criminal ganhava força, e,conseqüentemente, as teses a favor da abolição do júri. As críticas de Nelson Hungria contra o júri, porém, vão além da simples oposição leigos versus especialistas. $O$ especialista de Nelson Hungria é ainda mais especialista: é o jurista do tecnicismo jurídico-penal. A partir desse modelo, o próprio positivismo criminológico é colocado em questão por Hungria no que se refere ao problema do júri. Porém, Hungria não abdica completamente das razões do positivismo criminológico: ele opera com a série de argumentos mais típica do tecnicismo separada ou em conjunto com aquela do positivismo criminológico dependendo do contexto histórico no qual se move. É com esta chave - (in)distinção dos argumentos do tecnicismo jurídico-penal em relação àqueles do positivismo criminológico dependendo do contexto histórico - que a questão do júri em Nelson Hungria será abordada neste artigo.

$\mathrm{Na}$ conferência intitulada "A evolução do direito penal brasileiro" de 1942, o código penal de 1940 seria a última etapa desta evolução (HUNGRIA, 1943: 11). Como signo de evolução, o código é defendido com força em resposta aos críticos das soluções adotadas no novo texto legal. Em linhas gerais, Hungria tece essa defesa argüindo o acerto das soluções do código em relação às mais modernas doutrinas penais e criminológicas que teriam sido adequadamente adaptadas pela comissão à situação brasileira. Dada essa premissa, todo o problema estaria na correta aplicação da letra da lei nos tribunais e na necessidade de uma postura comprometida com a eficácia das normas codificadas por parte dos penalistas.

Depois de excluir criminologia, filosofia do direito penal, etc, do âmbito da ciência do direito penal em sentido estrito, isto é, aquela que compete exclusivamente aos juristas, Hungria conclui que "restam as ciências técnicas que instruem a justiça 
penal ou auxiliam a realização militante do direito penal" (HUNGRIA, 1942: 6). No esquema tecnicista, o trabalho do jurista começaria com a exegese da lei, para depois entrar na reconstrução dos institutos e do sistema já posto (a fase chamada de "dogmática" propriamente dita) a partir dos resultados da fase de exegese, e, por último - nem sempre citada por Hungria - a fase de 'crítica'. A exclusão das outras ciências no máximo utilizáveis, subsidiariamente, nos tribunais ou no processo de reforma das leis - e a "domesticação" da crítica ${ }^{4}$ são centrais para que o objetivo central do novo modelo de ciência do direito penal se realize: a colaboração com a efetivação das leis nos tribunais.

$\mathrm{Na}$ perspectiva do tipo de discurso penal que Nelson Hungria defendia, então, emergia como um sério problema a figura do advogado, em especial a do advogado do júri. $\mathrm{Na}$ relação tida como ideal por Hungria entre lei - doutrina jurisprudência, o embate em torno do júri condensa em si os argumentos mais significativos em relação ao terceiro elemento na construção imaginária deste tripé (ainda hoje fundamental no campo jurídico): a jurisprudência.

Para além da bondade intrínseca do texto legal, era necessário, para Hungria, eliminar os elementos perturbadores do bom funcionamento do sistema legislativo. Um desses elementos era o tribunal do júri, que teria sido, inclusive, um dos responsáveis pelo mau funcionamento do velho código penal de 1890. Mas antes de entrar na análise específica da conferência de 1942, retomemos o fio do contexto intelectual e institucional no qual Hungria levara a cabo seu embate.

Pode-se dizer que a formação jurídica do século XIX girava em larga medida em torno da figura do advogado, isto é, sublinhava a capacidade retórica do jurista, pautado no bom uso da palavra falada. Os corolários dessa opção são inúmeros. Entre elas a tendência em valorizar um ensino fundado na oralidade, onde a maioria dos textos que encontramos daquela época eram pensados, em verdade, para serem declamados ante um auditório determinado. Muito diferente do auditório impessoal dos padrões de cientificidade do final do século XIX que 
"A ELOQÜÊNCIA FARFALHANTE DA TRIBUNA DO JÚRI"....

atribuiria um valor muito maior à palavra impressa. Essa é a tese de Carlos Petit em seu trabalho sobre a cultura jurídica da Espanha Liberal no século XIX:

admitamos por um momento o paradoxo de colocar dentro do século XIX - o século da difusão social das letras, o século da linotipia e das revistas; sim, o século da lei escrita e do Estado um remoto entendimento que ainda esgota na tarefa do ius dicere o momento decisivo da criação jurídica (PETIT, 2000: 11) ${ }^{5}$.

Desse ponto de vista, no âmbito de uma cultura jurídica, segundo Petit, fundada no paradigma oratório-forense, a advocacia não é somente mais uma profissão jurídica entre tantas outras, mas a profissão jurídica por excelência:

sob o ponto de vista que ora se adota, o paradigma oratórioforense implica também promover a antiga advocacia, da sua atual condição de mera profissão jurídica (entre outras não menos desejáveis e dignas), para a categoria ontológica onde reina, solitário, o jurista perfeito (PETIT, 2000: 11).

A partir mais ou menos da década de 80 do século XIX, na Espanha, Petit marca o nascimento de um novo paradigma nas faculdades de direito: o do jurista-cientista. Pasquale Beneduce também identifica um processo similar na Itália, cujos primeiros embates e sinais "em torno do novo paradigma do jurista universitário que progressivamente subordina a si qualquer outra possível imagem do trabalho jurídico" ${ }^{7}$ se verificariam nas décadas de 60 e 70 do século XIX (BENEDUCE, 1996: 16-17). Paradigma que nasce sob o influxo do cientificismo, e que demanda toda uma série de práticas calcadas na escrita para se sustentar, e onde a retórica advocatícia passa a aparecer cada vez mais como uma forma de falsear a verdade.

Segundo Ricardo Fonseca, "esta passagem do jurista 'eloqüente' para o jurista 'cientista', grosso modo, pode ser transplantada para o caso da cultura jurídica brasileira (...)" (FONSECA, 2006: 361). No final do século XIX, Fonseca indica os 
inícios da passagem, no Brasil, do paradigma "eloqüente", para o paradigma "científico", e Wilton Silva também aponta que se afirmava uma "nova visão do conhecimento jurídico, realmente 'scientifica'" (SILVA, 2007: 31). Tobias Barreto, por exemplo, para ficar num caso da seara penal,

parecia não ter muito apreço pelo estilo retórico e grandiloqüente que marcou as gerações precedentes dos juristas brasileiros (como também da maior parte de seus contemporâneos), em vista de sua sempre ácida condenação ao que ele denominava a 'fraseologia'. Para ele, era uma tarefa importante insurgir-se "contra a frase, contra o estilo de salão que enfraquece o pensamento e corrompe os estudos sérios". (FONSECA, 2006: 364)

Isso não quer dizer, porém, que personagens como Tobias Barreto não carregassem as marcas da formação que criticavam. É famosa a crônica da eloqüente defesa da tese de doutorado de Tobias Barreto, do seu domínio da palavra falada (VENÂNCIO FILHO, 2004: 264).

O que importa, porém, no plano da história do pensamento jurídico, é que, desde o final do século XIX a figura do advogado (ainda mais se for advogado do júri) passa a ser alvo privilegiado daqueles juristas comprometidos com essa transformação no modelo de discurso jurídico, cada vez mais orientado para o cientificismo, contra aquilo que chamaríamos de "bacharelismo liberal" (ADORNO, 1988).

Para tomar um exemplo mais tardio, mais próximo do período deste trabalho, temos um discípulo de Tobias Barreto: Viveiros de Castro. No prefácio de seu livro sobre a "Nova Escola Penal" (referência ao positivismo criminológico), ele se insurge contra a retórica advocatícia, referindo-se a ela como marca de uma geração “(...) corroída até a medula pela rhetorica, pelo gosto do palavriado inane, balofo, frívolo. A sciencia moderna positiva, exacta, fria, irrita-lhe os nervos." (CASTRO, 1913: 11)

Já na crítica de Hungria à retórica do advogado do júri, o ponto central é o descaso pela eficácia do direito penal positivo. 
"A ELOQÜÊNCIA FARFALHANTE DA TRIBUNA DO JÚRI"....

Segundo ele, esse período marcado pelos oradores do júri teria produzido um direito penal "romântico e emocional", direcionado somente aos "êxitos tribunícios",

para cujo triunfo se torcia e retorcia o direito positivo [...], reduzido a letra morta pelo soberano arbítrio e lógica de sentimento do tribunal popular. O caluniado código de 90 fôra metamorfoseado, pela espetacular e profusa oratória criminal, desorientadora da justiça ministrada pelos juízes de fato, num espantalho ridiculamente desacreditado. Foi o período áureo do passionalismo sanguinário, que andava à solta, licenciado sob a estapafúrdia rubrica de "privação dos sentidos". As teorias revolucionarias da chamada "nova escola penal", difundidas à la diable, mal compreendidas ou tendenciosamente utilizadas, era a moeda que, embora sem autorização legal, mas sob o pretexto de deplorável atraso da nossa lei escrita, livremente circulava nos recintos do tribunal dos jurados. A literatura psiquiátrica, a lobrigar o patologismo nas mais fugidias discordâncias de conduta, era piamente acreditada e abria a porta da prisão a uma privilegiada chusma de sicários e rapinantes. (HUNGRIA, 1943: 13-14. Grifos meus)

Hungria e alguns dos expoentes do positivismo criminológico estão de acordo, portanto, no que tange aos males da retórica advocatícia de um modo geral. Mas é interessante notar que é justamente esse caráter de "exatidão" que Nelson Hungria negava ao saber do positivismo criminológico, acusando-o de, com as suas imprecisões e com os intermináveis debates contra o "classicismo", ter contribuído com a retórica tribunícia que corroeria a eficácia da norma penal positiva. Nesse sentido, bem notou a historiadora Joseli Mendonça que muitos dos embaraços da justiça penal nesse momento advinha "da atuação dos advogados de defesa que, como Evaristo de Moraes, instrumentalizavam os (des)conhecimentos das ciências médicas para ampliar a 'classe' dos agentes inimputáveis" (MENDONÇA, 2004: 344). O livro de memórias de Evaristo de Moraes, "Reminiscências de um rábula criminalista" (1989) é uma confirmação eloqüente da existência desse tipo de uso do 
positivismo criminológico durante a Primeira República no Brasil. Evaristo de Moraes conta, às vezes com riquezas de detalhes, varias ocasiões em que apropriou-se das teorias lombrosianas (e afins) com êxitos bastante distantes da almejada "defesa social" ou da efetividade das normas positivas.

Não é à toa a avaliação ambígua de Hungria acerca de Evaristo de Moraes, lamentando que o momento em que vivera, época de vivacidade do debate entre as escolas penais, o teria impedido de deixar para a posteridade um livro de estudo técnico-jurídico do direito vigente: "mesmo aqueles que conheciam, de verdade, a autêntica ciência penal abstinham-se, pelo receio de compromissos doutrinários em contraste com o interesse profissional, de fixar em livros didáticos a austera interpretação do direito positivo", e completa, "haja vista aquele que foi príncipe entre eles, o insigne Evaristo de Moraes, em cuja extensa bagagem literária não se depara um só estudo de feição estritamente técnico-jurídica" (HUNGRIA, 1943: 14. Grifo meu). Surpreende, aliás, os elogios de Hungria a Evaristo de Moraes: este, advogado rábula, conhecidíssimo pelas suas façanhas retóricas no tribunal do júri durante a Primeira República no Rio de Janeiro, encaixa-se quase como o tipo ideal de advogado do júri que, para o tecnicismo hungriano, teriam trazido todos os malefícios para a ciência do direito penal brasileira.

Sobre esses dois filões de críticas ao júri (em nome da Ciência em geral ou em nome da Lei em particular), Roberto Lyra (talvez o mais famoso dos penalistas contemporâneos de Nelson Hungria), ao defender o tribunal popular, distinguia, exatamente, duas posturas críticas em relação ao júri: "equivocam-se os que depreciam o júri sob o crivo técnicojurídico ou técnico-científico" (LYRA, 1975: 134). Ou seja, podese dizer que o positivismo criminológico crítica o júri e a figura do advogado em nome da ciência (crivo técnico-científico), e o tecnicismo de Nelson Hungria o faz em nome da lei (crivo técnico-jurídico). Isso não quer dizer que esses dois planos não possam entrecruzar-se, mas, nesta conferência de Hungria, eles são claramente diferenciados, tanto é que o positivismo 
“A ELOQÜÊNCIA FARFALHANTE DA TRIBUNA DO JÚRI"....

criminológico é, ao contrário, acusado de colaborar para a perpetuação da retórica enganadora dos advogados do júri.

Tão importante para Nelson Hungria era a questão do júri que ele considerava mesmo as recentes mudanças na estrutura desse tribunal o ponto de partida da "transformação evolutiva" na direção de um saber jurídico penal "ponderado" e realmente comprometido com a eficácia das normas. Mudanças que limitavam a competência legal do tribunal popular, e aumentavam, conseqüentemente, a dos juízes togados, bem como submetia as decisões do júri à revisão do Tribunal de Apelação. Os juízes togados - daí a importância dessas mudanças -, seriam, para ele, tendencialmente mais aptos a resistirem à retórica enganadora dos advogados. Passava-se, para ele, da "eloqüência farfalhante da tribuna do júri" à "dialética ponderada, sóbria e leal na exegese, análise e aplicação dos textos legais". Nas palavras de Hungria,

Com o declínio (...) do tribunal do júri, teve de operar-se uma profunda mudança nos arraiais da justiça penal. Transferido dos juizes de fato aos juizes de direito o julgamento da maioria dos crimes, entrou de despontar, no debate da solução dos casos e questões penais, o que se pode chamar de "pudor jurídico". Elevou-se o nível da cultura jurídico-penal. A eloqüência farfalhante da tribuna do júri foi substituída pela dialética ponderada, sóbria e leal na exegese, análise e aplicação dos textos legais (HUNGRIA, 1943: 15)

Essas transformações no tribunal do júri às quais Hungria se referia são, em grande parte, aquelas do decreto-lei $\mathrm{n}^{\circ} 167$, de 5 de janeiro de 1938, sob o regime de Vargas, como também do próprio código de processo penal de 1941. Segundo relatório produzido pelas instâncias administrativas governamentais, seriam modificações que pretendiam recuperar o "prestígio" do júri:

essa lei [o referido decreto $\mathrm{n}^{\circ} 167$ de 1938] integrou definitivamente o tribunal popular no aparelhamento de defesa da sociedade, livrando suas decisões das influências pessoais e 
restabelecendo o prestígio que ele vinha perdendo. A mais sensível das inovações operadas pelo decreto-lei $n^{\circ} 167$ foi a faculdade que conferiu aos Tribunais de Apelação para, em recurso, conhecer do mérito das decisões do júri e reformá-las, seja para absolver, seja para aplicar-lhe a pena merecida. Os dispositivos da lei do júri foram reproduzidos no Código de Processo Penal, com as alterações impostas pela experiência e pelo sistema de aplicação da pena adotado no novo Código Penal (SCHWARTZMAN, 1982: 85).

Uma mudança significativa no processo do júri levado a cabo não muito tempo depois do golpe que instituiu o Estado Novo: a outorga da Constituição de 1937 data do mês de novembro, e o decreto-lei 167 é de janeiro de 1938. Sinal de que o controle das forças centrifugas que poderiam atuar no tribunal popular em detrimento da "defesa social" (palavra de ordem adotada pelo regime na política criminal) era considerado bastante urgente.

A "lógica do sentimento" que a exposição de motivos denuncia como principal defeito do júri popular deveria ser o ponto a ser devidamente controlado pela nova lei, para que o tribunal popular pudesse transformar-se, como os outros tribunais togados, em um eficaz dispositivo estatal de defesa social. Enrijecimento do controle penal contra qualquer "indulgência para com criminosos":

Já não se pode compreender que alguns cidadãos, investidos na função de juízes de fato, se sobreponham, incontrastavelmente, às exigências da justiça penal, na sua finalidade de defesa da sociedade. A lógica do sentimento, que serve às decisões do Júri, não pode redundar em escandalosa indulgência para com criminosos (CAMPOS, 1938: 228).

Ainda na Exposição de Motivos do decreto-lei 167, Francisco Campos justifica que o júri não foi abandonado porque poderia colaborar para a "educação cívica do povo". O argumento de que o júri teria sido abolido tacitamente pela Constituição de 1937, já que ela não o mencionava (ao contrário 
"A ELOQÜÊNCIA FARFALHANTE DA TRIBUNA DO JÚRI"....

do texto constitucional anterior), é rechaçado por Campos. Não abolir o júri, mas adequá-lo às feições do novo regime, contra um tipo de tribunal popular, segundo ele, resquício do Império:

$\mathrm{O}$ que se tornou indissimulavelmente antinômico com o atual regime político, orientado primacialmente na defesa do preponderante interesse coletivo, ate agora embaraçado pelas demasias de um anacrônico liberalismo individualista, foi o Júri que o Império nos legara, o Júri ilimitadamente soberano e irresponsável (CAMPOS, 1938: 228).

Em suma, o governo aplica no júri um golpe duríssimo, ainda que não tenha adotado a tese da abolição do tribunal popular.

As críticas ao júri circulavam também em outros cantos do mundo, como na Itália - "pátria" dos maiores expoentes do positivismo criminológico. Críticas que, mesmo quando não se aceitava a pura e simples abolição, exigiam alguma resposta, clamando por reformas institucionais. As respostas não foram unívocas: na Itália, por exemplo, o regime fascista adotou o chamado scabinato, onde jurados leigos e juízes togados compartilhavam da função de julgar, sem a divisão de funções tradicional (ROCCO, Alfredo, 1931: 604; LONGHI, 1932: 183; Regio Decreto 23 marzo 1931, n. 249).

Embora o problema na relação novo código - júri que Nelson Hungria e Francisco Campos levantavam fosse muito similar ao que se discutia na Itália - Silvio Longhi sintetizou muito bem a questão dizendo que "o maior tecnicismo assumido pelo novo código penal deveria tornar ainda mais intolerável qualquer intervenção de profanos" (LONGHI, 1932: 182) ${ }^{8}$ - a resposta brasileira foi mais moderada, ainda que tocasse igualmente um pilar fundamental da instituição do júri ao relativizar a soberania dos seus julgamentos.

$\mathrm{O}$ art. 96 do decreto-lei 167 de 1938 estipulava que "se, apreciando livremente as provas produzidas (...), o Tribunal de Apelação se convencer de que a decisão do júri nenhum apoio encontra nos autos, dará provimento à apelação, para aplicar a 
pena justa, ou absolver o réo, conforme o caso." O recurso contra sentença manifestamente contrária às provas dos autos, atualmente, redunda em protesto por novo júri, repetição do julgamento, para não ferir o dispositivo constitucional que considera soberanas as decisões do tribunal popular, diferentemente da solução adotada pelo referido decreto-lei 167 de 1938 que afirmava a reformabilidade direta da sentença pelo Tribunal superior. Ou seja, a ausência de referência ao júri na Constituição de 1937 abriu o caminho para que uma lei ordinária relativizasse a soberania do tribunal popular.

$\mathrm{Na}$ mesma edição da Revista Forense onde, como de costume, esta norma foi divulgada para o meio jurídico, juntamente com a Exposição de Motivos do ministro da Justiça, acompanhava o comentário do jurista Magalhães Drumond sobre a nova disciplina do júri, e, tratando do tema mais delicado - a reformabilidade das decisões - o texto legal era defendido nos seguintes termos:

Há muito quem veja nisso um perigo para os réus. Penso que perigo haverá para os réus merecedores de condenação. É necessário não esquecer que o nosso juiz togado é - também psiquicamente - brasileiro, e como tal não concorrerá para que a justiça penal do Brasil se anti-humanize. Os Juizes dos Tribunais de Apelação vão julgar, brasileiramente, sentimentalmente, eticamente, tais quais os juízes populares, apenas com a diferença de poderem apreciar muito mais utilmente a prova do fato e a personalidade do criminoso. Por outro lado, sabedores de que suas deliberações estão sujeitas a tal revisão, os jurados vigiar-se-ão mais na sua sentimentalidade, procurarão objetivar mais as causas que julguem, de modo a que possam ver comprovadas as suas decisões. (DRUMOND, 1938: 224)

Para defender que a reforma das decisões do júri não seria um perigo para os réus, Magalhães Drumond apela para 0 estereótipo da sentimentalidade inerente ao povo brasileiro em geral, e, assim, do vínculo sentimento - humanismo. Porém, aproximando-se, na segunda parte, do pensamento de Nelson Hungria acerca de sentimento/romantismo versus 
“A ELOQÜÊNCIA FARFALHANTE DA TRIBUNA DO JÚRI"....

objetividade/cientificidade no campo penal, a possibilidade de as decisões do júri serem revistas por juízes togados forçaria os jurados a serem menos sentimentais, "objetivando mais as causas que julgam".

De resto, é bastante claro o argumento do positivismo criminológico: a incapacidade dos jurados de decidirem sobre questões profundamente científicas e especializadas como a personalidade do criminoso. Um argumento, aliás, que já fora usado anteriormente na discussão sobre o novo código penal. Aureliano Correa de Araújo, por exemplo, relator do parecer da congregação da Faculdade de Direito de Recife sobre o projeto de Código Penal Sá Pereira ( $n^{\circ} 118-A$ de 1935) escrevia que

o projeto neste ponto incide nas constantes censuras que se increpavam e se increpam às leis vigentes, que, em relação ao Tribunal popular, armam os juizes leigos das graves atribuições de julgar questões técnicas relativas ao estado mental dos criminosos, sem conhecimento de princípios elementares de psico-patologia forense (CORREA, 1937: 45)

A reforma levada a cabo sob a égide do Ministro Campos, porém, não se limitou à relativização da soberania do júri. Conforme explica o próprio Francisco Campos na Exposição de Motivos do decreto-lei,

além da reformabilidade das decisões do Júri pelos Tribunais de Apelação, foram introduzidas as seguintes inovações: a) fortalecimento da autoridade e maior amplitude de ação do presidente do Tribunal do Júri; b) critério positivo de maior rigor na seleção dos jurados; (...) e) redução do tempo dos debates, para evitar que estes degenerem em discussões acadêmicas ou torneios de retórica (...). (CAMPOS, 1938: 228)

O segundo ponto aparecia no artigo $7^{\circ}$ : "Os jurados devem ser escolhidos dentre os cidadãos que, por suas condições, ofereçam garantias de firmeza, probidade e inteligência no desempenho da função". O "povo" do tribunal popular não é qualquer um. Sob o Estado Novo, a seleção desse "povo" deveria 
ser ainda mais rigorosa. Apesar disso, a fórmula utilizada pela lei brasileira é bastante genérica em comparação com outras soluções análogas, isto é, que buscavam controlar de maneira mais estrita a "qualidade" dos jurados. É o caso da lei italiana: também modificada nesse aspecto pelo regime fascista, o artigo 4 do Regio Decreto 23 marzo 1931 n. 249 que trata dos requisitos para alguém se tornar jurado é bastante extenso e detalhado, ao contrário do dispositivo brasileiro que é sucinto, genérico, e, também, menos objetivo.

A inovação da lei brasileira mencionada no item "e" da Exposição de Motivos de Francisco Campos ("redução do tempo dos debates, para evitar que estes degenerem em discussões acadêmicas ou torneios de retórica") nos faz lembrar imediatamente a argumentação de Hungria, anteriormente mencionada, acerca da retórica enganadora dos advogados do júri. Já que não se optou por abolir o tribunal popular, a solução encontrada foi diminuir o tempo dos debates.

O art. 9, por sua vez, institui formas de responsabilização do jurado, "nos mesmos termos em que o são os juízes de oficio, por prevaricação, inexaçao, peita ou suborno (...)." Este artigo, juntamente com o art. 96, são aqueles que atingiam mais diretamente o indesejado traço "ilimitadamente soberano e irresponsável" do tribunal popular, e, na medida em que o juiz togado era o modelo de bondade para juristas como Campos e Hungria, adotar medidas como essa, que aproximavam o jurado do juiz, eram, para eles, claramente desejáveis.

Completando a reforma penal desejada pelo regime de Vargas, é elaborado também um novo Código de Processo Penal. Em relação ao júri, o ministro Francisco Campos afirmava, em 1939, a substancial continuidade entre o projeto de novo Código e o Decreto-Lei 167 de 1938:

Com ligeiros retoques, foram mantidos no corpo do projeto os dispositivos do Decreto-Lei número 167, de 5 de janeiro último, que regula a instituição do júri. Como atestam os aplausos recebidos, de vários pontos do País, pelo governo da República, e é notório, têm sido excelentes os resultados desse decreto 
"A ELOQÜÊNCIA FARFALHANTE DA TRIBUNA DO JÚRI"....

legislativo, que veio afeiçoar o tribunal popular ao ritmo das instituições do Estado Novo. A aplicação da Justiça penal pelo júri deixou de ser uma abdicação para ser uma delegação do Estado, que se reserva o direito de ajustá-la à feição do interesse social. Privado de sua antiga soberania, que redundava, na prática, numa sistemática e alarmante indulgência para com os réus, o júri está, agora, integrado na consciência de suas graves responsabilidades e reabilitado na confiança geral. (CAMPOS [1939], 2001: 123)

Os "ligeiros retoques" mencionados por Campos seriam modificações que serviriam, segundo Hungria, para "afeiçoar o tribunal popular ao sistema do novo Código Penal" (HUNGRIA, 1941: 17). Uma delas seria um aumento do tempo para os debates (art. 68 do Decreto-Lei 167 modificado pelo art. 474 do $\mathrm{CPP}$ ); e outra seria aquela que

limita a função julgadora do Conselho de Sentença a afirmar ou negar o fato criminoso e sua autoria, as circunstâncias elementares ou qualificativas, a desclassificação do crime eventualmente pleiteada e as causas excludentes de pena ou de crime. Quando veredictum for no sentido da condenação, ao juiz presidente do tribunal incumbe fixar a pena e impor medida de segurança, lavrando sentença cumpridamente motivada. É incontestável que semelhante tarefa não podia ser confiada à justiça sentimental ou emotiva do tribunal popular (HUNGRIA, 1941: 17. Grifo meu)

A queda do Estado Novo e o advento da Constituição de 1946, porém, mudariam essa paisagem que Nelson Hungria não só contemplava satisfeito, mas que também participara em primeira pessoa para construir. Dessa vez, são aqueles favoráveis ao tribunal do júri que avaliam positivamente as mudanças: "A Constituição de 1946, obra do povo, por intermédio de seus legítimos representantes, restaurou o júri naquilo que ele tinha de mais essencial, a sua soberania"; invocando a "tradição milenária do tribunal popular", Alfredo Albuquerque retoma a denúncia segundo a qual na omissão da 
Constituição de 1937 estava a intenção de abolir o júri e critica as transformações trazidas pelo decreto-lei 167 de 1938:

Coisa assim tão velha não se pode extirpar facilmente, como o tentou fazer a Carta Constitucional de 1937, dando lugar a protestos, a que o Governo ditatorial teve de atender, sendo, então, expedido o dec.-lei $\mathrm{n}^{\circ} 167$ de 1938. Mas este decreto, desvirtuando a instituição milenar, pode-se dizer que o amputou numa de suas características essenciais, a soberania de suas decisões (ALBUQUEROUE, 1946: 405)

$\mathrm{Na}$ Constituição de 1946, o júri é regulado no capítulo acerca das garantias individuais, e o parágrafo dedicado a ele estabelece parâmetros mínimos a serem seguidos pela lei que o regulamentaria em 1948:

Art. 141, § 28, CF 1946 - É mantida a instituição do júri, com a organização que lhe der a lei, contanto que seja sempre ímpar o número dos seus membros e garantido o sigilo das votações, a plenitude da defesa do réu e a soberania dos veredictos. Será obrigatoriamente da sua competência o julgamento dos crimes dolosos contra a vida.

Ao ir além da simples menção ao júri, isto é, estabelecendo diretrizes para a futura regulamentação, percebe-se claramente a proteção que o texto constitucional pretendia atribuir ao tribunal popular contra aquilo que era considerado 'esvaziar' a instituição. Os dois pontos principais, neste aspecto, são a menção à soberania dos veredictos e a garantia de um rol mínimo de competência (os crimes dolosos contra a vida), que são exatamente os dois flancos pelos quais o Estado Novo teria 'esvaziado' o júri. Lembremos do elogio de Hungria à limitação da competência do júri e à relativização da soberania dos seus veredictos na conferência de 1942.

O projeto de lei que regularia o júri é exatamente o Projeto de Lei do Senado $n^{\circ} 1$ de 1946, apresentado pelo senador Olavo Oliveira do Partido Social Progressista. Evidentemente, a regulamentação o mais imediata possível do júri é uma questão 
“A ELOQÜÊNCIA FARFALHANTE DA TRIBUNA DO JÚRI"....

de adequado funcionamento da Justiça, mas, de qualquer forma, tamanha presteza na apresentação do projeto de regulamentação indica, também, a valência política simbólica do tribunal popular no processo de reforma da herança institucional da ditadura de Vargas.

O autor deste projeto de lei, senador Olavo Oliveira, criticava com eloqüência a disciplina anterior do tribunal do júri:

A Constituição de 10 de novembro de 1937, conservando a competência privativa da União para legislar sôbre o direito processual (art. 16, $\mathrm{n}^{\circ} \mathrm{XVI}$ ), fez tábua rasa do Júri, como garantia constitucional e como órgão do poder judiciário. E veio o Decretolei $\mathrm{n}^{\circ} 167$, de 5 de janeiro de 1938, profundo golpe nos tradicionais sentimentos democráticos do nosso país. A título de regular a instituição do Júri, reduziu o velho e querido tribunal popular a uma verdadeira ficção, submetendo as suas decisões à reforma dos Tribunais de Justiça, que armou de autoridade para absolver e condenar os acusados, contra os pronunciamentos dos Conselhos de Sentença, no julgamento das apelações interpostas das suas decisões (OLIVEIRA, 1949: 13)

A lei $n^{\circ} 263$ de 1948 - resultado do PLS n 1 de 1946 - para salvaguardar a soberania do júri no caso da previsão do Código de Processo de Penal de apelação por decisão manifestamente contrária aos autos estabeleceu que a decisão do Tribunal de togados só poderia determinar um novo julgamento pelo tribunal popular. Quanto à competência, o seu art. $2^{\circ}$ parágrafo $1^{\circ}$ aumentou as hipóteses do art. 74 do Código de Processo Penal: as várias formas de aborto foram incluídas na esfera de competência do júri, juntamente com o homicídio doloso, 'induzimento, instigação e auxilio ao suicídio' e infanticídio que já eram de sua competência pela lei anterior.

É esse o novo contexto que Hungria encontra depois da queda do Estado Novo quando publica na Revista Forense, em 1956, um artigo intitulado "A justiça dos jurados". Entre as lembranças das leis que outrora ele próprio ajudara a elaborar e o novo desenho institucional da Constituição de 1946, Hungria sentenciava:

HISTÓRIA, São Paulo, 28 (2): 2009 
Foi em vão que o nosso Cód. Penal vigente cuidou de criar obstáculos à proverbial frouxidão do tribunal popular. Valiam eles ao tempo em que a lei substantiva e a lei adjetiva penais, entrosadas em um sistema harmônico, que veio a ser rompido pelo desgraçado art. 141 § 28, da Constituição de 46, se completavam para a eficiência da repressão do crime. (HUNGRIA, 1956: 10)

Em oposição ao legislador de 38 (do decreto-lei 167) e de 41 (do Código de Processo Penal), a Constituição de 1946 era acusada de sucumbir aos interesses da categoria dos advogados:

A reforma que em tão boa hora fôra realizada pelo legislador de 38 e 41 veio a ser anulada sumariamente por uma emenda de afogadilho ao projeto de Constituição de 46, obtida pela cabala e a pressão dos advogados criminais no Palácio Tiradentes. (HUNGRIA, 1956: 11)

Para compreender a dimensão desta crítica, vale lembrar, ainda, que a menção aos advogados criminais remete à velha imagem negativa do advogado do júri que já aparecia na conferência de Hungria publicada em 1943.

No novo clima de restauração da democracia, a influência do fascismo torna-se um grave problema, e, para defender a solução de outrora, esconjurar este argumento é ponto de passagem obrigatório:

Afirmou-se, insidiosamente, que a revogada possibilidade de alteração de meritis dos veredictos do júri pelo tribunal togado (...) tinha cor fascista ou cheiro de Estado totalitário. Pura invencionice, mero boato demagógico. O exemplo viera da Inglaterra, pátria do júri (...). Foi a Inglaterra que teve a iniciativa, nos tempos modernos, apesar do ferrenho conservantismo que a caracteriza, da reformabilidade das decisões do júri pela Corte de Justiça, chegando a admitir, ainda quando o recurso seja do próprio réu, até mesmo a reformatio in pejus. (HUNGRIA, 1956: 11) 
"A ELOQÜÊNCIA FARFALHANTE DA TRIBUNA DO JÚRI"....

Entrando no cerne da argumentação de Hungria, tomemos uma longa passagem como ponto de partida da análise:

Vivemos em um século em que a chave do progresso é a divisão do trabalho e a especialização das funções. Na amplitude e complexidade crescente dos dados da experiência científica, o êxito de qualquer arte, oficio ou profissão esta condicionado ao particularismo e tecnicismo de conhecimentos. O especialista e o técnico são os procurados e escolhidos, porque só eles realizam o ideal prático dos right men in the right places. A improvisação, ainda que lastreada pela mais provida inteligência e o mais equilibrado bom-senso, já não pode ter possibilidade de sucesso. (...) Nenhum mister, por mais aparentemente fácil que seja, dispensa preparo e treinagem singularizados. Pois bem; há um setor da vida social que ainda se exime ao "imperativo categórico" da convocação dos capazes, persistindo em oficializar o "culto da incompetência": é o da administração da justiça penal, com a rotineira conservação do famigerado Tribunal do Júri. (...) A justiça penal tornou-se, com os modernos estudos biopsico-sociologicos do criminoso e do crime, uma função que envolve a aprofundada pesquisa da alma humana (...). Já não pode deixar-se inspirar por sentimentalismos espúrios, por ódios vingativos ou ditames de piedade. (...) A justiça penal emocional cedeu o passo à justiça penal friamente analítica, ao serviço do superior e exclusivo interesse da defesa social contra o flagelo da criminalidade (HUNGRIA, 1956: 8).

O especialista contra o leigo; o sentimentalismo contra a 'frieza analítica'; todos argumentos que lembram o positivismo criminológico. De fato, nem sempre positivismo e tecnicismo operam em binários opostos ou em rota de colisão. Muito embora Hungria defendesse que a magistratura togada preveniria a justiça penal tanto dos "ódios vingativos" quanto dos "ditames de piedade", a "defesa social" colocada como pedra de toque empurra o seu pensamento menos na direção das garantias individuais e mais nas necessidades da repressão estatal. Além disso, a 'defesa social' é um dos laços que permitem tecnicismo e positivismo encontrar-se no âmbito de reformas institucionais. 
Na seqüência da argumentação, Hungria insiste na crítica à retórica tribunícia e ao despreparo dos jurados para não se deixarem levar por ela (HUNGRIA, 1956: 9), e a ênfase na defesa social faz com que ele se preocupe mais com a retórica dos advogados de defesa, que falam por último e seriam, por isso, mais capazes de conseguir uma absolvição:

O 'monstro' (...) descrito pela Promotoria Publica vai, aos poucos, pelo "passe de mágica" da defesa insidiosa e eloqüente, sempre a falar por último, adquirindo asas de anjo, véu de serafim, auréola de santo, fardão de benemérito, e o resultado é sabido: absolvição unânime e com louvor. (HUNGRIA, 1956: 9)

Ao discutir a distinção entre direito e fato, a obsessão pela defesa social mais uma vez faz pender as críticas mais fortes à retórica da defesa:

(...) ainda que fosse viável a distinção entre fato e direito, qual a utilidade de reservar a apreciação daquele ao júri, se, ao fim de oito horas de palavrório sonoro, o fato se apresenta à percepção e ao espírito dos jurados inteiramente outro do que realmente ocorreu, totalmente diverso do constante nos autos, não passando, já então, de um "ente de razão" criado, artificialmente, pela sofisteria e lances teatrais do defensor, que sempre merece do júri mais crédito que o promotor, contra quem há a prevenção de que somente acusa por dever funcional. (HUNGRIA, 1956: 11)

Contra o argumento do "povo distribuindo Justiça", Hungria procura reduzi-lo ao absurdo, e se pergunta por que não se defende a participação popular em todos os assuntos de administração do Estado? (HUNGRIA, 1956: 9). A única conclusão possível, para Hungria, é que a manutenção do júri deve-se unicamente ao interesse particularístico dos advogados criminais e ao "coronelismo de aldeia":

(...) o povo não se preocupa em que se lhe de, ou não, a prerrogativa de julgar. O júri só lhe interessa como espetáculo, como show, como tablado de rink (...). O 'coronelismo' de aldeia e 
“A ELOQÜÊNCIA FARFALHANTE DA TRIBUNA DO JÚRI"....

o unilateralismo interesseiro dos advogados criminais é que bradam pela manutenção do júri soberano, para que não cessem os seus proveitosos triunfos eleitorais ou profissionais (HUNGRIA, 1956: 9).

Depois de destilar uma série de argumentos muito comuns ao positivismo criminológico, Hungria retoma aquilo que considerei anteriormente um pilar fundamental da argumentação tecnicista contra o júri, isto é, a efetividade judicial das leis penais: "O júri, na realidade prática, é a anomalia de um sistema instituído e montado para violar impunemente as leis, sem estar obrigado, sequer, a fundamentar seus julgados." (HUNGRIA, 1956: 10)

No texto mais antigo de Hungria, a articulação entre os argumentos positivistas e tecnicistas é bem mais fraca porque ainda era muito recente a memória dos usos tribunícios das próprias teorias positivistas, no seio do mal fadado, segundo ele, debate das escolas penais. Em 1956, essa memória já era mais fraca, e Hungria pôde direcionar todas as suas energias contra os argumentos "liberais", utilizando todos os estratos semânticos possíveis do "imaginário anti-júri", incluindo aqueles do positivismo criminológico.

Os argumentos fundados na autoridade da ciência e na autoridade da lei convergem, ao final da estrada, na apologia do especialista, do técnico, compreendidos em sentido genérico, não necessariamente técnico no sentido mais particular do tecnicismo jurídico-penal.

Apesar disso, a distinção entre essas duas séries de argumentos não é inócua, pois, de outro modo, não seria possível dar a devida consideração aos diferentes contextos históricos pressupostos por Hungria. O primeiro é composto pela preocupação com: a) os usos tribunícios do positivismo criminológico; b) a afirmação do tecnicismo jurídico-penal; c) os "malefícios" do próprio debate das escolas penais; d) as disputas de espaço entre magistrados e médicos no campo jurídico-penal, onde o positivismo criminológico tendia a aumentar o espaço destes últimos (ALVAREZ, 1996; RIBEIRO 
FILHO, 1994). Além, é claro, da contraposição em relação aos argumentos "demo-liberais" a favor do júri. Já o segundo contexto no qual se move o texto de 1956 é assaz diferente, pois, embora os argumentos sejam fundamentalmente os mesmos e redutíveis a um mesmo esquema teórico, a própria repetição também chama a atenção do historiador, interessado na singularidade dos acontecimentos.

O próprio texto traz as marcas das mudanças que merecem ser destacadas. A começar pelo uso mais despreocupado de argumentos muito característicos do positivismo criminológico para atacar o júri. Este é o sinal mais eloqüente de que, para Hungria, o contexto já não é mais aquele do embate contra os usos tribunícios do positivismo criminológico ou do confronto contra o debate das escolas penais. Interpõe-se, entre a conferência de 1942 e o texto de 1956, a queda do Estado Novo, o advento da Constituição de 1946. Neste novo ambiente, o decreto-lei 167 de 1938 já não é mais o ponto de partida para uma etapa superior da ciência do direito penal no Brasil, mas a recordação de uma evolução interrompida e caluniada por aqueles que a consideraram fruto de uma concepção fascista. O art. $141 \S 28$ da Constituição de 1946 (e a sua respectiva lei de regulamentação) é o alvo privilegiado - quase exclusivo, se compararmos com os diversos alvos atingidos por Hungria na conferência de 1942.

Nos dois textos há o claro tom polêmico e arguto que marcou aqueles que conheceram Nelson Hungria ${ }^{9}$, mas o segundo é muito mais melancólico, por assim dizer. Evidentemente, porque as transformações no direito positivo não acompanharam as suas convicções como outrora, mas também porque o embate contra uma norma positivada, para um tecnicista como Hungria, é particularmente difícil, pois o coloca no limite (talvez além) daquilo que ele próprio considera o papel essencial de um jurista. Basta lembrar dos ataques que o mesmo Hungria lançava contra aqueles que criticavam excessivamente o Código Penal de 1890, pouco contribuindo para a sua pratica aplicação e traindo os seus deveres como juristas. 
"A ELOQÜÊNCIA FARFALHANTE DA TRIBUNA DO JÚRI"....

$\mathrm{Na}$ medida em que o tecnicismo de Hungria procurou afastar a "crítica" do coração da ciência do direito penal, reduzindo-o a "meras sugestões ao legislador", epifenômeno da dogmática, a altissonante crítica de Hungria, em 1956, ao referido artigo da Constituição de 1946, adquire esse traço melancólico, pela marginalidade que este brado teoricamente ocupa em seu esquema de pensamento.

Ainda a respeito do que revela essa oposição de Hungria à nova disciplina do júri em relação ao seu pensamento jurídico, além da "melancolia", vem à tona o "arquivo escondido" do tecnicismo. As críticas de Nelson Hungria ao júri não provém de uma simples posição política pessoal, mas são conseqüências extraídas da sua concepção de direito. Ou seja, Hungria não pede licença ao "jurídico" para falar de "política" quando critica o júri tal qual estava positivado em 1956. Esse é o instante em que o seu tecnicismo descola-se daquilo que deveria ser a sua necessária base legislativa, e, como sistema transformado em modelo, possibilita que o jurista Hungria possa opor-se à legislação positiva.

Em relação ao júri depois da queda do Estado Novo, não há um mínimo denominador comum (político) entre o sistema transformado em modelo de política legislativa e a disciplina positiva do instituto em questão, de modo que o embate a partir do "arquivo escondido" de Hungria redundou na forte oposição do artigo de 1956. Muito embora o tecnicismo seja bastante dúctil - particularmente na tentativa de sempre acompanhar a legislação positiva - a nova disciplina do júri chocava com alguns princípios básicos do pensamento jurídico de Hungria.

O objetivo fundamental do tecnicismo, não só na versão de Nelson Hungria, era colaborar com os juízes para uma adequada aplicação da norma positivada, conseqüentemente, um jurado, que não tem o conhecimento da ciência jurídica, correria sempre o risco de não aplicá-la corretamente, elidindo a sua efetividade judicial, bem como a defesa social colocada como objetivo político final de todo o sistema penal. É nesse sentido que a nova disciplina do júri, retomando princípios daquilo que Hungria considerava um anacrônico e indesejável liberalismo, 
perturbava as bases mais profundas do tipo de saber jurídico que ele advogava; bases que adquiriam, nessas condições, algum valor prescritivo, muito embora se tratasse, agora, de um embate contra a lei positiva: em tese, o limite do tecnicismo.

Os últimos anos de vida de Hungria teriam sido marcados por alguns repensamentos. Segundo René Ariel Dotti, Nelson Hungria teria revisto, parcialmente, a "sentença de maldição lançada contra o júri, admitindo a grandeza dos debates do tribunal popular" (DOTTI, 2003: 218-219). O marco dessa virada seria a carta-prefácio de Hungria ao segundo volume do livro "Os Grandes Processos do Júri" de Carlos Araújo de Lima. Segundo Hungria, esse livro encerraria um "notável trabalho de fixação da "poeira de ouro" da eloqüência que vocês, oradores do tribunal popular, espalham perdulariamente ao vento" (HUNGRIA [1953] 1996: vii). Sublinhemos, porém: Hungria referese à "poeira de ouro"; o próprio livro pretende trazer os grandes processos do júri. Naquela época, o livro "Comentários ao Código Penal" de Nelson Hungria já era famosíssimo, tanto é que era muito citado também nos debates do júri, e a carta termina fazendo referência a esse fato: "sinto-me tão envaidecido com isso que chego quase a me reconciliar com o tribunal do povo..." (HUNGRIA [1953], 1996: vii. Grifo meu). O "quase" desta penúltima frase da carta deve ser enfatizado, pois, em comparação com a grandeza da "sentença de maldição", com o vínculo bastante estreito entre as críticas ao júri e a concepção de direito de Hungria, o tom positivo que ele adota em relação ao tribunal popular na referida carta-prefácio deve ser bem sopesado. Além disso, uma questão factual: a altissonante crítica do artigo "A justiça dos jurados" é de 1956, enquanto a carta-prefácio é de 1953, logo, essas palavras mais mansas não bloquearam os duros golpes de três anos depois. Portanto, na conclusão de Dotti, devemos sublinhar com força a palavra 'parcialmente'.

Onze anos antes da carta-prefácio encontramos, ainda, outra esfumatura interessante do pensamento de Hungria. É preciso lê-la ao contrário, porém, pois ele se refere ao magistrado 
“A ELOQÜÊNCIA FARFALHANTE DA TRIBUNA DO JÚRI"....

togado. No seu discurso de posse como desembargador do Tribunal do Distrito Federal, Hungria afirmou que

ao juiz não se faz mister inteligência privilegiada ou farta munição de cultura. O que lhe é necessário, antes de tudo, é o espírito de ponderação, o ritmo psíquico, o equilíbrio moral, numa palavra: o bom senso. (...) O bom senso, o avisado e lhano bom senso dispensa os raciocínios sutis e os arabescos da dialética (...) Os complexos tratados de sabedoria jurídica e psicologia judiciária não valem por certo, as sentenças de Sancho Pansa na ilha da Barataria (HUNGRIA, 1944: 572)

Essas críticas de Nelson Hungria a determinados erros dos juízes togados não podem senão lembrar o modelo por antonomásia de justiça penal: o júri. Exatamente o júri era defendido por ser lugar do bom senso em oposição ao mecanicismo formalista do juiz togado; exatamente os tratados de psicologia judiciária eram invocados pelos positivistas como razão primeira para não confiar a juizes leigos a justiça penal. Porém, as críticas de Hungria ao "juiz técnico-apriorístico", ao "juiz-burocrata" (HUNGRIA, 1944: 573), devem ser bem compreendidas. O contexto, em 1944, é bastante favorável: o júri parece controlado através das mudanças introduzidas pelo decreto-lei de 1938, e, posteriormente, pelo Código de Processo Penal de 1941. Criticar certo tipo de postura da magistratura togada arriscando a aproximar-se do júri parece não preocupar, tanto é que esse problema não aparece no discurso de Hungria. Além disso, ele não exclui a necessidade de conhecimentos técnicos por parte do juiz. O bom senso não substitui a técnica, mas opera como salutar limite, principalmente em relação ao juiz no exercício do seu trabalho que é prático, e não teórico, em última instância. Nas palavras de Hungria,

longe de mim afirmar que o juiz não deve ilustrar-se, consultando a lição doutrinária e pondo-se em dia com a evolução jurídica; mas, se ele se deixa seduzir demasiadamente pelo teorismo, vai dar no carrascal das subtilitates juris e das abstrações inânes, distanciando-se do solo firme dos fatos, para aplicar, não a 
autêntica justiça (...) mas um direito cerebrino e inumano (HUNGRIA, 1944: 573)

A questão, para Hungria, é claramente quantitativa: se a apreciação da personalidade do criminoso não é adequada para o júri porque demanda saberes especializados, o juiz togado também não pode exagerar; se a doutrina jurídica é passagem obrigatória para um magistrado, não se pode exagerar nem mesmo aqui, pois seu compromisso é com a lei e com a prática administração da justiça penal. Aliás, a própria doutrina jurídica não pode exagerar: ainda dentro de uma perspectiva tecnicista, Hungria criticava os "excessos da lógica formal", que trairiam, também, os objetivos práticos da concepção de saber jurídico do próprio tecnicismo (HUNGRIA, 1940; 1942; 1949).

O tema do júri vai aparecer novamente na famosa campanha de Hungria, em 1959, contra a pena capital imposta a Caryl Chessman, no Estado da Califórnia, EUA. Segundo Nelson Hungria, Chessman teria sido vitima do excesso de rigor de um júri "composto quase exclusivamente de mulheres, tiroidianamente emotivas e aprioristicamente inclinadas à vingança dos imputados assaltos contra moças indefesas". Tendo se defendido sozinho, "alheio aos truques tribunícios", Chessman teria capitulado diante do "terrivelmente hábil promotor Miller Leavy" (HUNGRIA apud DOTTI, 2003: 234) ${ }^{10}$.

Extraindo ensinamentos contra aqueles que pretendiam reintroduzir a pena capital no direito penal brasileiro e criticando, mais uma vez, o júri, Hungria afirmava:

Quando se tem conhecimento de casos como o de Chessman, que, em virtude de certos indícios e uma confissão que ele insiste em declarar extorquida pela violência, foi condenado à pena última pela justiça emocional do júri, sempre disposta a atirar, do alto da varanda de Pilatos, bodes expiatórios à multidão sedenta de vingança, é que se vê como estão distanciados da verdadeira solução do problema da grande criminalidade esses que, entre nós, presentemente, insistem em querer introduzir o assassínio oficial entre as sanções do nosso Código Penal comum. (HUNGRIA apud DOTTI, 2003: 229. Grifo meu) 
“A ELOQÜÊNCIA FARFALHANTE DA TRIBUNA DO JÚRI"....

Além do uso do velho estereótipo da emotividade feminina, vale sublinhar alguns outros aspectos que têm interesse para o desenvolvimento do tema deste artigo: entre os "ódios vingativos" e os "ditames de piedade" que afligiriam o júri, aqui a preocupação recai, naturalmente, nos 'ódios vingativos'; a "sentença de maldição" contra o júri é reafirmada, mais uma vez, quatro anos depois das palavras mais mansas da cartaprefácio citada anteriormente.

Embora a questão da pena de morte no pensamento de Nelson Hungria não seja o objeto deste trabalho, ela deve ser considerada aqui, por um momento, em relação ao que foi dito sobre o "arquivo escondido" do tecnicismo, isto é, da sua capacidade de, em alguns momentos, transformar-se de modelo descritivo a modelo prescritivo em relação à legislação positiva. Uma campanha contra a pena de morte, em um primeiro momento, poderia parecer mais um desses momentos, já que encontramos, no caso, um jurista tecnicista colocando em suspenso, por assim dizer, a sua função primordial de colaborar na correta aplicação judicial das normas positivas, em nome de um empenho cívico. No caso das críticas ao júri, porém, este empenho provinha claramente da sua concepção de direito tecnicista, do seu modelo de método jurídico. No caso da pena de morte, esse vínculo já não é tão claro - se existe é muito mais frágil em comparação com a questão do júri. O lugar dos juristas, a especificidade do 'jurídico' e do seu saber não são ameaçados pela permanência ou não da pena de morte no ordenamento jurídico.

Evidentemente, a discordância do jurista em relação a determinadas soluções do ordenamento jurídico é prevista pelo esquema tecnicista. Depois da exegese da norma já posta, depois da reconstrução dogmática do sistema existente, sucede, é verdade, a terceira fase: a crítica ${ }^{11}$. Crítica, porém, que em comparação com o momento da "reconstrução dogmática do sistema" é claramente marginal: não passa de "meras sugestões ao legislador" (HUNGRIA, 1942: 8). O caso da pena de morte e o embate contra o júri mostram, porém, que essa crítica pode adquirir tons diferenciados. A diferença, aqui, é o vínculo mais 
ou menos estreito com a própria concepção de direito tecnicista. $E$ É melhor dizer, portanto, que o tecnicismo enquanto tal transforma-se em modelo prescritivo muito mais no caso do júri.

As críticas de Nelson Hungria ao tribunal popular, aos descaminhos que os advogados do júri teriam imprimido na cultura jurídico-penal brasileira, são parte integrante do contexto histórico marcado pelo forte embate contra o chamado "bacharelismo liberal". Um embate que pode ser compreendido, também, dentro do esquema da passagem do paradigma do "jurista eloqüente" para o "jurista cientista", que, no Brasil, remonta às últimas décadas do séc. XIX e atravessa toda a Primeira República. Literatos como Monteiro Lobato ([1919] 1964), Lima Barreto ([1923] 2001) e Oswald de Andrade ([1924] 1978) também participaram, nesse período, da construção do sentido negativo do termo "bacharelismo". Ao longo da Primeira República, na esfera política, o bacharel "passa a dividir espaços com outras elites de natureza cada vez mais tecnocrática" (SILVA, 2005: 17; GOMES, 1994) e a ciência jurídica elaborava as suas respostas: entre elas encontramos 0 positivismo criminológico e o tecnicismo jurídico-penal.

O tribunal popular, no âmbito dessas transformações, aparece como um grave problema. O tribunal do júri e o advogado do júri acabam se transformando, no imaginário de muitos juristas, como lugares de reprodução da velha e indesejada retórica típica do bacharelismo liberal do Império.

Roberto Lyra, na época, já indicava que existiam críticas ao júri do ponto de vista "técnico-científico" e "técnico-jurídico". De fato, na conferência de Hungria de 1942 essa diferenciação é relevante, pois, a série de argumentos fundados na autoridade da lei, isto é, na necessidade de garantir a efetiva aplicação da norma positivada (algo que o júri não seria capaz de fazer em virtude da incapacidade dos jurados de resistirem à retórica dos 
"A ELOQÜÊNCIA FARFALHANTE DA TRIBUNA DO JÚRI"....

advogados), são lançados também contra o positivismo criminológico, acusado de, no final, contribuir para a reprodução da retórica enganadora do júri forçando a aplicação de orientações não adotadas pelo ordenamento jurídico.

Os argumentos fundados na autoridade da ciência e na autoridade da lei convergem, ao final da estrada, na apologia do especialista, do técnico, compreendidos em sentido genérico, não necessariamente técnico no sentido mais particular do tecnicismo jurídico-penal. É o que acontece no artigo de 1956 de Hungria "A Justiça dos jurados".

Apesar disso, a distinção entre essas duas séries de argumentos também é importante para dar a devida consideração aos diferentes contextos históricos pressupostos por Hungria. O primeiro é composto pela preocupação com: a) os usos tribunícios do positivismo criminológico; b) a afirmação do tecnicismo jurídico-penal; c) os "malefícios" do próprio debate das escolas penais; d) as disputas de espaço entre magistrados e médicos no processo penal, onde o positivismo criminológico tendia a aumentar o espaço destes últimos. Além, é claro, da contraposição em relação aos argumentos "demo-liberais" a favor do júri.

Já o segundo contexto com o qual dialoga o texto de 1956 de Hungria já não é mais aquele do embate contra os usos tribunícios do positivismo criminológico ou do confronto contra o debate das escolas penais. Interpõe-se, entre a conferência de 1942 e o texto de 1956, a queda do Estado Novo, o advento da Constituição de 1946. Neste novo ambiente, o decreto-lei 167 de 1938 já não é mais o ponto de partida para uma etapa superior da ciência do direito penal no Brasil, mas a recordação de uma evolução interrompida e caluniada por aqueles que a consideraram fruto de uma concepção fascista. O art. $141 \S 28$ da Constituição de 1946 (e a sua respectiva lei de regulamentação) é o alvo privilegiado - quase exclusivo, se compararmos com os diversos alvos atingidos por Hungria na conferência de 1942. Os argumentos da série "autoridade da ciência" e "autoridade da lei" convergem na crítica ao que Hungria considerava um anacrônico "demo-liberalismo". 
A forte crítica de Hungria ao júri, enfim, aparece como a amarração final de um pensamento que buscava a maior coerência possível entre as concepções de código/lei, saber jurídico e aplicação da lei. Uma determinada forma de conceber a relação entre esses três elementos que marca, ainda hoje, a postura considerada "tradicional" frente ao direito.

\section{Referências Bibliográficas}

ALBUQUERQUE, Alfredo. O júri em face da nova constituição. Revista Forense, Rio de Janeiro, set. 1946.

ADORNO, Sérgio. Os Aprendizes do Poder: o bacharelismo liberal na política brasileira. Rio de Janeiro: Paz e Terra, 1988.

ALVAREZ, Marcos C. Bacharéis, criminologistas e juristas: saber jurídico e nova escola penal no Brasil (1889-1930). São Paulo, 1996. Tese (Doutorado em Sociologia) - FFLCH, USP. Orientador: Sérgio Adorno.

ANDRADE, Oswald. Manifesto da Poesia Pau-Brasil [1924]. In: TELES, Gilberto Mendonça. Vanguarda Européia e Modernismo Brasileiro. $5^{\mathrm{a}}$ ed. Petrópolis: Vozes, 1978.

BARRETO, Lima. Os Bruzundangas: incluindo outras histórias dos bruzundangas [1923]. 3. ed São Paulo: Ática, 2001.

BENEDUCE, Pasquale. Il corpo eloquente: identificazione del giurista nell'Italia liberale. Bologna: Il Mulino, 1996.

BRASIL. Decreto-lei $n^{\circ} 167$ de 1938.

BRASIL. Decreto-lei n ${ }^{\circ} 2.848$ de 7/12/1940 (código penal).

BRASIL. Decreto-lei n 3.689 de 3/10/1941 (código de processo penal).

BRASIL. Lei n 263 de 1948.

BRASIL. Tramitação Projeto de Lei do Senado n ${ }^{\circ} 1$ de 1946 (sen. Olavo Oliveira). Disponível em: http://www.senado.gov.br/sf/atividade/materia/detalhes.asp?p co $\mathrm{d}$ mate $=74473$ Acesso em: 18 de novembro de 2008.

CAMPOS, Francisco. Exposição de motivos Lei 167/1938. Revista Forense, janeiro 1938. 
“A ELOQÜÊNCIA FARFALHANTE DA TRIBUNA DO JÚRI"....

. Síntese da Reorganização Nacional [1939]. In: . $\mathrm{O}$

Estado Nacional. Brasilia: Senado Federal, 2001.

CASTRO, Viveiros de. A Nova Escola Penal. Rio de Janeiro: Jacintho Ribeiro dos Santos Editor, 1913.

CORREA, Aureliano Correa de. O projeto de Código Criminal do Brasil. Recife: Imprensa industrial, 1937.

CONSTITUIÇÃO dos Estados Unidos do Brasil de 18 de setembro de $1946 . \quad$ Disponível em: http://www.planalto.gov.br/ccivil_03/constituicao/Constitui\%C3\%A 7ao46.htm Acesso em: 25/06/2009.

DOTTI, René Ariel. Nelson Hungria: o passageiro da divina comédia. In: RUFINO, Almis Gasquez; PENTEADO, Jaques de Camargo (orgs.). Grandes juristas brasileiros. São Paulo: Martins Fontes, 2003.

DRUMOND, Magalhães. O júri no Estado Novo. Revista Forense, Rio de Janeiro, jan. 1938.

FONSECA, Ricardo M. Os juristas e a cultura jurídica brasileira na segunda metade do século XIX. Quaderni Fiorentini per la Storia del Pensiero Giuridico Moderno, Milano, vol. XXXV, t. I, 2006.

GOMES, Ângela de Castro. Novas Elites Burocráticas. In:

(org.). Engenheiros e economistas: novas elites burocráticas. Rio de Janeiro: Ed. FGV, 1994.

HUNGRIA, Nelson. A evolução do direito penal brasileiro. Revista Forense, Rio de Janeiro, jul. 1943.

out. 1942.

. Introdução à Ciência Penal. Revista Forense, Rio de Janeiro,

. Código de Processo Penal e Lei das Contravenções. Revista Forense, Rio de Janeiro, nov. 1941.

166, 1956.

A justiça dos jurados. Revista Forense, Rio de Janeiro, vol.

. Carta de Nelson Hungria. In: LIMA, Carlos Araújo de. Os grandes processos do júri. Vol. II. 4. ed. Rio de Janeiro: Lumen Juris, 1996.

. Desembargador Nelson Hungria: discurso de posse. Revista Forense, Rio de Janeiro, ago. 1944.

. O tecnicismo jurídico-penal. In: . Questões jurídico-

penais. Rio de Janeiro: Livraria Jacintho, 1940. 
out. 1942.

. Introdução à Ciência Penal. Revista Forense, Rio de Janeiro,

. Os pandectistas do direito penal [1949]. In:

Comentários ao código penal. Vol. I, tomo II. Rio de Janeiro: Forense, 1978.

ITALIA. Regio Decreto 23 marzo 1931, n. 249.

LOBATO, José Bento Monteiro. Cidades Mortas [1919]. São Paulo: Brasiliense, 1964.

LONGHI, Silvio. La nuova Corte di assise in Italia. In: Scritti teoricopratici sulla nuova legislazione penale italiana. Vol. I. Bologna: Zanichelli, 1932.

LYRA, Roberto. Direito Penal Normativo. Rio de Janeiro: José Konfino, 1975.

MARTINELLI, Thiago. O Tribunal do Júri no Estado Novo Reflexões acerca de um instituto jurídico amado e odiado. In: 1 MOSTRA DE PESQUISA (CAXIF/UFSC), 2007. Anais... Porto Alegre: Editora Dom Quixote, 2007. Digital.

MENDONÇA, Joseli. Evaristo de Moraes: Justiça e Política nas Arenas Repúblicanas (1887-1939). Campinas, 2004. Tese (Doutorado em História) - UNICAMP. Orientadora: Sílvia Hunold Lara.

MORAES, Evaristo. Reminiscências de um Rábula Criminalista. $2^{a}$ ed. Rio de Janeiro: Briguiet, 1989.

OLIVEIRA, Olavo. O Júri na Terceira República. Rio de janeiro: Freitas Bastos, 1949.

PADOA-SCHIOPPA, Antonio. La giuria penale in Francia: dai 'philosophes' alla Costituente. Milano: LEL, 1994.

PETIT, Carlos. Discurso sobre el Discurso. Oralidad y Escritura en la Cultura Jurídica de la España Liberal. Huelva: Universidad de Huelva, 2000.

RIBEIRO FILHO, Carlos Antonio Costa. Clássicos e Positivistas no Moderno Direito Penal Brasileiro: uma interpretação sociológica. In: PEREIRA, Carlos Alberto Messeder; HERSCHMANN, Michael (org.). A invenção do Brasil moderno. Rio de Janeiro: Rocco, 1994.

ROCCO, Alfredo. La nuova corte d'assise. Rivista Penale, Roma, anno 1931-IX E.F.

ROCCO, Arturo. Il problema e il metodo della scienza del diritto penale. Rivista di diritto e procedura penale, vol. I, 1910. 
"A ELOQÜÊNCIA FARFALHANTE DA TRIBUNA DO JÚRI"....

SBRICCOLI, Mario. La penalistica civile. Teorie e ideologie del diritto penale nell'Italia Unita. In: COSTA, Pietro et al. Stato e Cultura Giuridica in Italia dall'Unità alla Repubblica. Roma: Laterza, 1990.

SILVA, Wilton. Os doutores advogados: elites e disputas políticas em um período de mudanças (1870-1930). Diálogo Jurídico, vol. VI, p. 27-44, 2007.

. Os guardiões da linguagem e da política: o bacharelismo na República Velha. Justiça \& História, Porto Alegre (RS), v. 5, n. 10, 2005.

SONTAG, Ricardo. Código e Técnica. A codificação penal de 1940 e a construção da identidade do penalista. Brasil (1930-1945). Florianópolis, 2007. Monografia (Graduação em História) - UDESC. Orientador(es): Maria Teresa Santos Cunha; Airton Cerqueira-Leite Seelaender.

SCHWARTZMANN, Simon (org.). O Estado Novo, um Auto-retrato. Arquivo Gustavo Capanema. Brasília: CPDOC/FGV, Ed. UnB, 1983. VENÂNCIO FILHO, Alberto. Das arcadas ao bacharelismo. 150 anos de ensino jurídico no Brasil. São Paulo: Perspectiva, 2004.

SONTAG, Ricardo. "A eloqüência farfalhante da tribuna do júri": the people's court and the law in Nelson Hungria. História, v.28, n.2, p.267-302, 2009.

Abstract: This article aims to explore the issue of the jury in Nelson Hungria's thought considering the historical context of the transformations suffered by the criminal law institutions during the "Estado Novo" (particularly the laws on the jury and the criminal code - 1940 - and criminal procedure code 1941) to the post scriptum of the process with the changes brought by the Constitution of 1946 and the law 268 of 1947 and his later writings. The key aspect to be considered in this process is the (in)distinction used by Hungria of the arguments of the criminal-legal technicism in relation to those of criminological positivism depending on historical context.

Keywords: Law history; Estado Novo; Jury; Nelson Hungria. 


\section{NOTAS}

${ }^{1}$ Um esboço com esse objetivo, do ponto de vista da história do pensamento jurídico, em: MARTINELLI, Thiago. O Tribunal do Júri no Estado Novo - Reflexões acerca de um instituto jurídico amado e odiado. In: 1 MOSTRA DE PESOUISA (CAXIF/UFSC), 2007. Anais... Porto Alegre: Editora Dom Quixote, 2007. Digital.

${ }^{2}$ Para um quadro bastante completo acerca do júri no contexto da afirmação do modelo moderno de direito, cf. PADOA-SCHIOPPA, Antonio. La giuria penale in Francia: dai 'philosophes' alla Costituente. PADOA-SCHIOPPA, Antonio. La giuria penale in Francia: dai 'philosophes' alla Costituente. Milano: LEL, 1994.

3 Para evitar confusão terminológica, esclareçamos desde já que o termo "positivismo criminológico", aqui, não se confunde com "positivismo jurídico". Positivismo criminológico quer se referir, especificamente, à tradição de Cesare Lombroso e de Enrico Ferri; aos estudos de "antropologia criminal", "sociologia criminal", "biopsicopatologia criminal", etc., que floresceram na esteira desses dois "pais fundadores". O termo, em verdade, é usado em sentido bastante amplo e sem debruçar-se nas possíveis diferenciações. Anotemos desde já, porém, uma diferença interna relativa ao objeto deste artigo: aquela entre o positivismo criminológico anti-júri (Viveiros de Castro, por exemplo), e o positivismo criminológico pró- júri (Evaristo de Moraes e Roberto Lyra, por exemplo). Mas aprofundar essa estrada já seria uma pesquisa autônoma. Ainda sobre a terminologia, o positivismo criminológico aparece nas fontes, às vezes, como "nova escola penal". Nova em relação ao "classicismo" da tradição cujo pater sempre referenciado é Francesco Carrara. O "debate das escolas" seria, então, entre "classicismo" e "positivismo criminológico". Um esquema muito simplificante, é evidente, mas como o objeto deste artigo não são as escolas penais do séc. XIX, não valeria a pena aprofundar-se nesse aspecto. Embora tecnicistas como Hungria apareçam, às vezes, como herdeiros do "classicismo", e, já que estamos, agora, no objeto especifico deste artigo, vale uma diferenciação para evitar a confusão entre tempos históricos distintos: o tecnicismo, aqui, não é tomado como sinônimo de classicismo, já que tanto na Itália, com Vincenzo Manzini e Arturo Rocco, p. e. (SBRICCOLI, 1990), como no Brasil com Nelson Hungria, a pretensão é 
"A ELOQÜÊNCIA FARFALHANTE DA TRIBUNA DO JÚRI"....

de superar o próprio debate das escolas. A expressão "positivismo jurídico" em sentido estrito (isto é, como uma qualificação da ciência do direito, e não só como um direito fundado em normas estatais positivadas) poderia ser identificado com o tecnicismo, mas, como o termo praticamente não aparece nas fontes consultadas para esse artigo e como ele pode ter sentidos muito diversos dependendo do filósofo do direito de referência, preferi, aqui, usar somente a expressão 'tecnicismo'.

4 Sobre essas transformações na ciência do direito penal, cf. SBRICCOLI, Mario. La penalistica civile. Teorie e ideologie del diritto penale nell'Italia Unita. In: COSTA, Pietro et al. Stato e Cultura Giuridica in Italia dall'Unità alla Repubblica. Roma: Laterza, 1990. Para o caso brasileiro, com especial atenção a Nelson Hungria, permito-me reenviar ao que já pude escrever em SONTAG, Ricardo. Código e Técnica. A codificação penal de 1940 e a construção da identidade do penalista. Brasil (1930-1945). Florianópolis, 2007. Monografia (Graduação em História) - UDESC. Orientador(es): Maria Teresa Santos Cunha; Airton Cerqueira-Leite Seelaender.

${ }^{5}$ Tradução Mônica Sol Glik. No original: "Admitamos por un momento la paradoja de colocar en el siglo XIX - el siglo de difusion social de las letras, el siglo de la linotipia y las revistas; sì, el siglo de la ley escrita y del Estado un remoto entendimiento que todavía agota en la tarea del ius dicere el momento decisivo de la creación jurídica."

${ }^{6}$ Tradução Mônica Sol Glik. No original: "Desde el punto de vista que ahora se adopta el paradigma oratório-forense implica además elevar a la vieja abogacía desde su actual condición de mera profesión jurídica (entre otras no menos deseables y dignas) a la categoría ontológica donde reina solitario el jurista perfecto."

${ }^{7}$ No original, em italiano: "intorno a quel nuovo paradigma del giurista universitario che progressivamente subordina a sé ogni altra possibile immagine del lavoro giuridico."

${ }^{8}$ No original: "(...) il maggior tecnicismo assunto dal nuovo codice penale doveva rendere vieppiù intollerabile qualsiasi intervento di profani".

${ }^{9}$ René Ariel Dotti, por exemplo, cita a saudação de Evandro Lins e Silva quando da aposentadoria de Nelson Hungria no Supremo Tribunal Federal onde era mencionada a "veemência da linguagem", as qualidades de polemista exímio com "eloqüência faiscante e dialética contundente" do ministro (DOTTI, 2003: 205) 
${ }^{10} \mathrm{O}$ texto é reproduzido na integra por René Ariel Dotti, trata-se da prolusão de Nelson Hungria no Centro Acadêmico da faculdade de Direito da Universidade de São Paulo em maio de 1959 intitulado "Um condenado à morte".

${ }^{11}$ Essa terceira fase ("crítica"), de fato, é bastante trascurada por Hungria nos seus textos metodológicos, muito embora existam referências esparsas acerca da existência desse momento ao longo da argumentação. De qualquer forma, essas três fases que constituem a dogmática jurídica tecnicista (1. exegese; 2. reconstrução dogmática do sistema ou dogmática em sentido estrito; e 3. crítica) é claramente delineada pelo expoente do tecnicismo italiano Arturo Rocco (1910), que é de onde Hungria empresta esse esquema, bem como a "domesticação" e marginalização do momento "crítico" e "reformista" da ciência do direito penal.

Artigo recebido em 08/2009. Aprovado em 10/2009. 